\title{
AN EXPERIMENTAL STUDY OF CONCRETE MIXED WITH COCONUT SHELL HUSK AS PARTIAL REPLACEMENT OF FINE AGGREGATE
}

\author{
S. Prakash Chandar, K.Gunasekaran, S. Saravanan* and R. Ramasubramani \\ Department of Civil Engineering, SRM IST, Kattankulathur-603203,Tamilnadu, India \\ E-mail: naveensaravanan95@gmail.com
}

\begin{abstract}
This study focuses on study on concrete mixed with coconut husk as partial replacement for fine aggregate the study includes on the properties of split tensile strength, compressive strength, flexural strength and impact resistance of concrete by using the coconut husk in range of 10\%, $20 \%, 30 \%, 40 \%, 50 \%$ of volume in conventional concrete. Coconut husk volume is optimized as $40 \%$ in control concrete for the replacement of river sand to achieve the strength. For the optimized percentage of coconut husk introduced in conventional concrete, mechanical properties such as split tensile strength, impact strength, and flexural strength tests were conducted and reported.

Keywords: Coconut Shell, Flexural Strength, Compressive Strength, Split Tensile Strength, Impact Test, Young's Modulus.
\end{abstract}

(C) RASĀYAN. All rights reserved

\section{INTRODUCTION}

The concrete utilization is increasing at a higher rate by the development of infrastructures. Because of more extraction of the concrete, there is continuous aggregate extraction from natural resources that leads to ecological imbalance and depletion. To manage the imbalance, the waste that is produced from coconut shell husk which is used in replacement of aggregates.In India, 90\% production of coconut is in south India. The coconut shell is crushed in crusher machine after sieving in sieve $4.75 \mathrm{~mm}$ coconut husk is collected. Coconut shell husk is used as recycled lightweight aggregate in concrete.

\section{Material used Cement}

\section{EXPERIMENTAL}

A binding material which is used to bond coarse aggregates and fine aggregates while water added to the mixture is cement. The specimen was cast by using cement of grade OPC 53. The most commonly used cement is ordinary Portland cement. Strength depends upon the quality of cement.

\section{Fine Aggregate}

Aggregates are inert granular materials consists of natural sand and crushed stone. The fine aggregate is passed through $4.75 \mathrm{~mm}$ sieve to avoid stones present in it. The specific gravity of fine aggregate is 2.65 . Zone II type of fine aggregate is moderate and recommended.

\section{Coarse Aggregate}

The aggregate which is more than $4.75 \mathrm{~mm}$ is known as Coarse aggregate. The material that is retained from crushed rock or crushed gravel. The Size of coarse aggregate used is $20 \mathrm{~mm}$. The specific gravity of coarse aggregate is 2.40 to 3.0 .

\section{Coconut Husk}

Coconut husk is obtained from crushed coconut shell by sieving in $4.75 \mathrm{~mm}$ sieve. Coconut husk contains lignin and cellulose and it has high calorific value. The chemical composition of coconut husk has charcoal, tar, tannin, and potassium. The specific gravity of coconut husk is 1.1.

Rasayan J. Chem., 12(3), 1621-1626(2019)

http://dx.doi.org/10.31788/RJC.2019.1235228

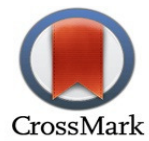


RASĀYAN J. Chem.

Vol. 12 | No. 3 |1621 - 1626| July - September | 2019

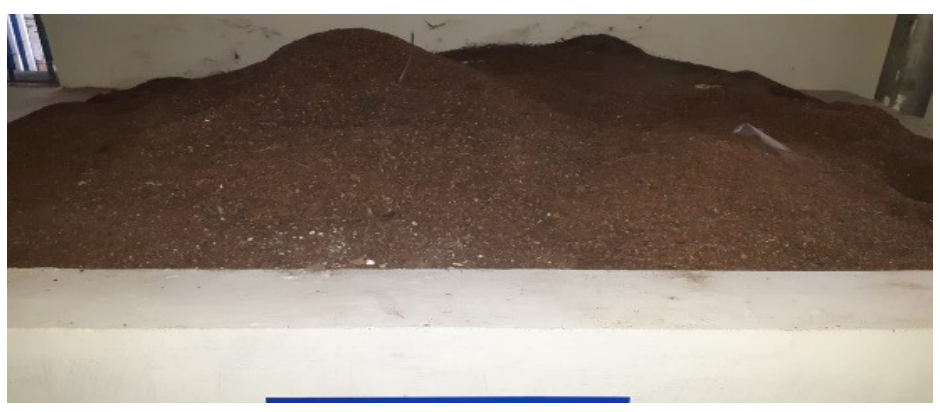

Fig.-1: Coconut Shell Husk

\section{Design mix}

In design mix for plain and reinforced concrete IS 456-2000 is used for reference of concrete mixes. M25 grade mix is used with a ratio of 1:1:2 and the water-cement ratio is 0.50 .

\section{Casting of Specimen}

The specimens are cast and the test should be conducted to know the flexural strength, compression test, split tensile test, impact test are tested with conventional and replacement of coconut-shell husk. Cube molds size of $150 \times 150 \times 150 \mathrm{~mm}$, cylinder molds of $150 \times 300 \mathrm{mmand}$ for flexural beam $100 \times 100 \times 500 \mathrm{~mm}$. This specimen is tested in the intervals of 3, 7, 28 days.

\section{Curing of Specimen}

Curing of a specimen is done to achieve two main factors considering to maintain a stable temperature and to prevent loss of moisture content in a specimen. The optimum curing temperature of the specimen is $20^{\circ} \mathrm{C}$. The specimen is done curing to achieve strength.

\section{Compression Strength Test}

The concrete specimens of size $150 \times 150 \times 150 \mathrm{~mm}$ of control concrete and replacement of coconut shell husk were tested under compression for 3,7 and 28 days and the readings were tabulated. Compressive strength is given by load to the area as shown in Fig.-4.

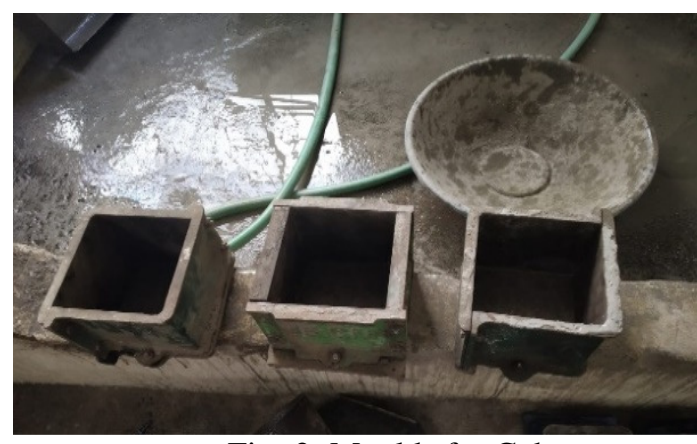

Fig.-2: Moulds for Cubes

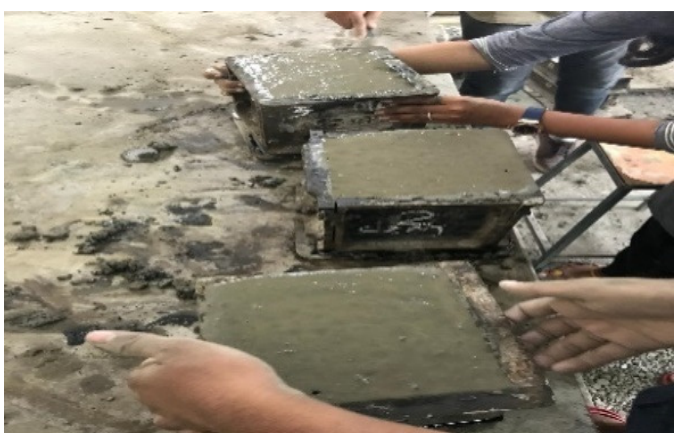

Fig.-3: Cast Specimen

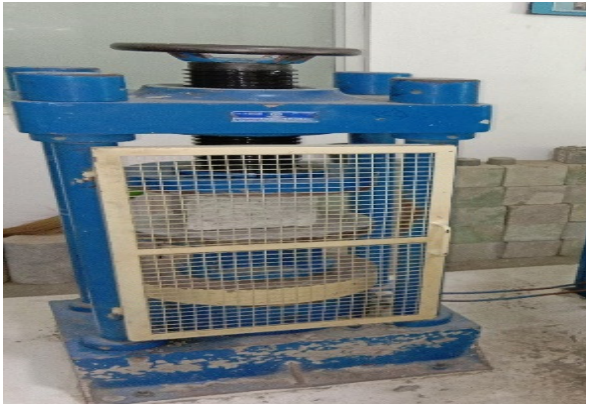

Fig.-4: Compressive Strength Testing on Cube

1622 
RASĀYAN J. Chem.

Vol. 12 | No. 3 |1621 - 1626| July - September | 2019

Table-1: Compression Strength Test

\begin{tabular}{c|c|c|c|c|c}
\hline \multirow{2}{*}{ Mix type } & \multirow{2}{*}{$\begin{array}{c}\text { Replacement of } \\
\text { Coconut shell husk in } \\
(\%)\end{array}$} & \multirow{2}{*}{$\begin{array}{c}\text { Density } \\
\text { Kg/m3 }\end{array}$} & \multicolumn{3}{|c}{ Compressive strength N/mm2 } \\
\cline { 4 - 6 } & 0 & 2480 & 15.4 & 20.8 & 29.12 \\
\hline Control Concrete & $10 \%$ & 2462 & 15.1 & 19.3 & 29.0 \\
\hline \multirow{4}{*}{$\begin{array}{c}\text { Coconut shell husk } \\
\text { concrete }\end{array}$} & $20 \%$ & 2401 & 14.6 & 18.6 & 28.7 \\
\cline { 2 - 6 } & $30 \%$ & 2370 & 13.9 & 18.1 & 27.56 \\
\cline { 2 - 6 } & $40 \%$ & 2323 & 13.7 & 17.8 & 26.13 \\
\cline { 2 - 6 } & $50 \%$ & 2301 & 12.6 & 16.2 & 24.8 \\
\hline
\end{tabular}

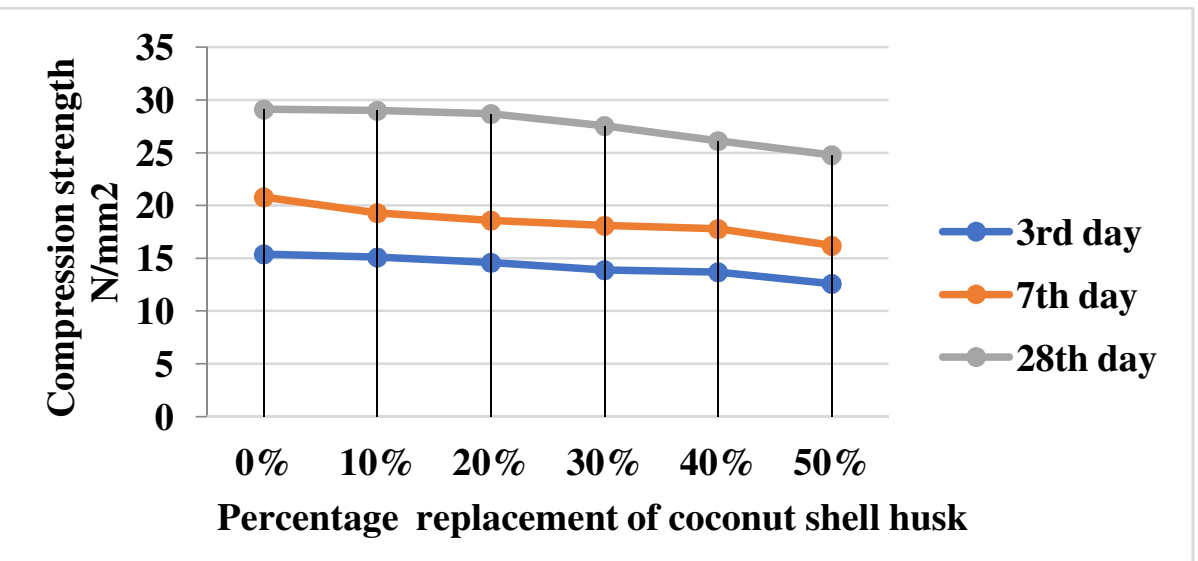

Fig.-5: Graphical Representation of Compression Strength Test Results

\section{Split Tensile Strength Test}

The conventional concrete specimens and replaced specimen of size $150 \times 300 \mathrm{~mm}$ are tested under split tensile strength shown in Fig.-6. At the center of the cylinder specimen, the tensile loads are applied. The formula for split tensile strength is $\mathrm{F} \alpha=2 \mathrm{P} / \pi \mathrm{dl}$. Where $\mathrm{P}$ - load is given to the specimen, 1 and $\mathrm{d}$ are denoted as length and diameter of the specimen.

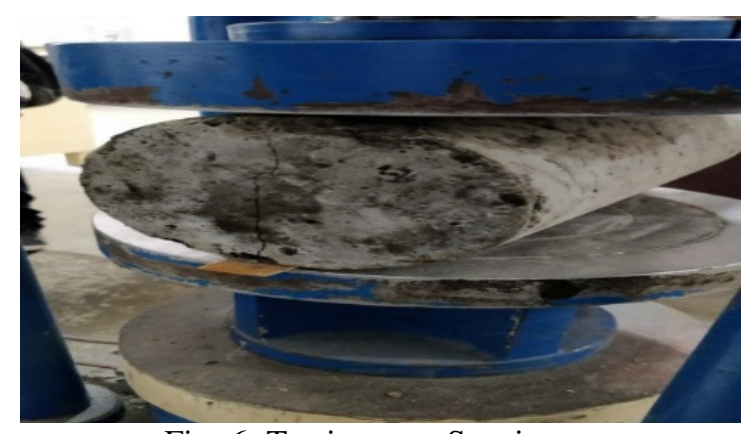

Fig.-6: Testing on a Specimen

Table-2: Split Tensile Strength Test Results

\begin{tabular}{c|c|c|c|c}
\hline \multirow{2}{*}{$\begin{array}{c}\text { Mix Type } \\
\text { Control concrete }\end{array}$} & $\begin{array}{c}\text { Replacement of } \\
\text { Coconut Shell } \\
\text { Husk in (\%) }\end{array}$ & $3^{\text {rd }}$ day & $7^{\text {th }}$ day & $28^{\text {th }}$ day \\
\cline { 2 - 5 } & $0 \%$ & 2.66 & 2.93 & 4.6 \\
\hline \multirow{5}{*}{$\begin{array}{c}\text { Coconut shell husk } \\
\text { concrete }\end{array}$} & $10 \%$ & 2.57 & 2.81 & 4.2 \\
\cline { 2 - 5 } & $20 \%$ & 2.31 & 2.59 & 3.63 \\
\cline { 2 - 5 } & $30 \%$ & 2.12 & 2.45 & 2.27 \\
\cline { 2 - 5 } & $40 \%$ & 2.07 & 2.32 & 2.49 \\
\hline
\end{tabular}




\section{Flexural Strength Test}

The specimen was taken and the center to center distance is marked and kept under loading at the center point in compression testing machine. At some point, it gets cracked and the readings are noted as shown in Fig.-7.

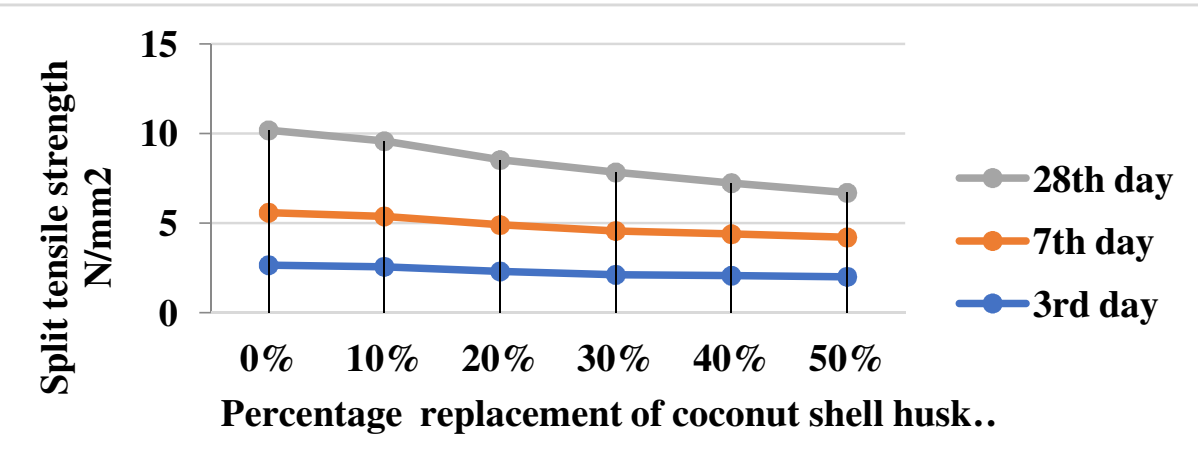

Fig.-7: Graphical Representation of Split Tensile Strength Test Results

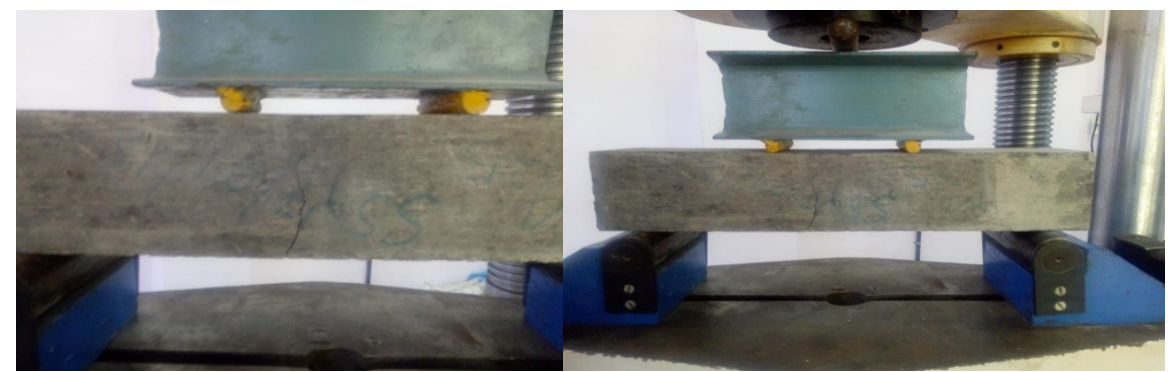

Fig.-8: Testing of Flexural Beams

Table-3: Flexural Strength Test Results

\begin{tabular}{c|c|c|c|c}
\hline \multirow{3}{*}{ Mix Type } & Replacement of Coconut & \multicolumn{3}{|c}{ Flexural Strength N/mm } \\
\cline { 2 - 5 } & Shell Husk in $(\%)$ & $3^{\text {rd }}$ day & $7^{\text {th }}$ day & $28^{\text {th }}$ day \\
\hline Control concrete & $0 \%$ & 2.84 & 4 & 5.65 \\
\hline \multirow{4}{*}{$\begin{array}{c}\text { Coconut shell } \\
\text { husk concrete }\end{array}$} & $10 \%$ & 2.72 & 3.72 & 5.13 \\
\cline { 2 - 5 } & $20 \%$ & 2.54 & 3.24 & 4.7 \\
\cline { 2 - 5 } & $30 \%$ & 2.13 & 2.8 & 4.13 \\
\cline { 2 - 5 } & $40 \%$ & 1.66 & 2.5 & 3.8 \\
\hline
\end{tabular}

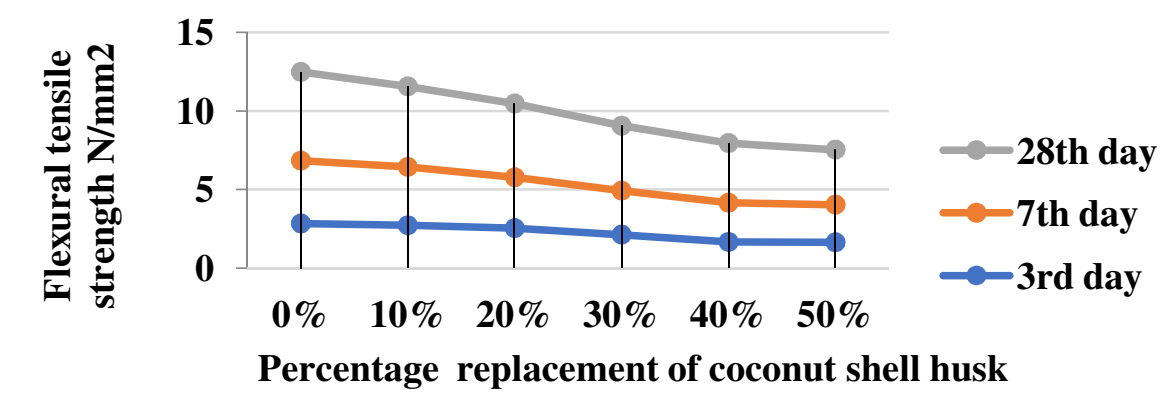

Fig.-9: Graphical Representation of Flexural Strength Test

\section{Impact Resistance Test}

The specimen was placed at the center of impact testing machine above which metal ball is placed on which continuous hammering was done until it gets a break as shown in Fig.-9. 


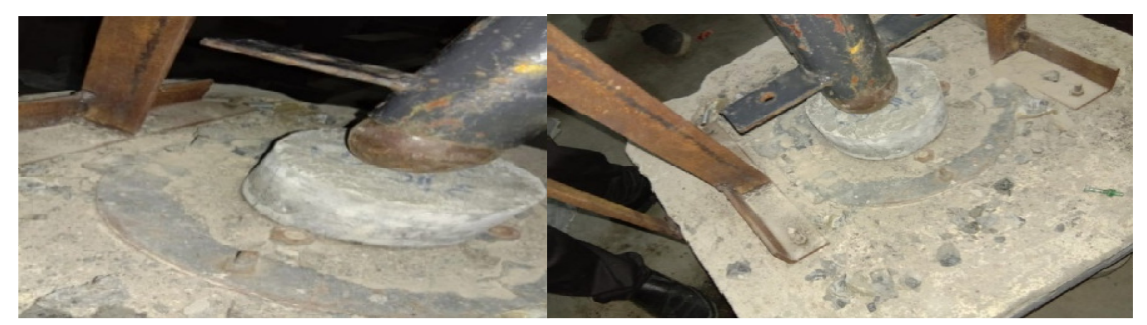

Fig.-10: Testing of Concrete Disc

Table-4: Impact Resistance Test

\begin{tabular}{|c|c|c|c|c|c|c|c|}
\hline \multirow{3}{*}{ Mix Type } & \multirow{3}{*}{$\begin{array}{c}\text { Replacement of } \\
\text { Coconut Shell } \\
\text { Husk in }(\%)\end{array}$} & \multicolumn{6}{|c|}{ Impact Resistance Test } \\
\hline & & \multicolumn{2}{|c|}{$3^{\text {rd }}$ day } & \multicolumn{2}{|c|}{$7^{\text {th }}$ day } & \multicolumn{2}{|c|}{$28^{\text {th }}$ day } \\
\hline & & Initial & Final & Initial & Final & Initial & Final \\
\hline Control concrete & $0 \%$ & 45 & 49 & 51 & 56 & 75 & 83 \\
\hline \multirow{5}{*}{$\begin{array}{l}\text { Coconut shell } \\
\text { husk concrete }\end{array}$} & $10 \%$ & 24 & 27 & 55 & 58 & 86 & 102 \\
\hline & $20 \%$ & 55 & 59 & 64 & 69 & 112 & 124 \\
\hline & $30 \%$ & 56 & 61 & 92 & 95 & 145 & 152 \\
\hline & $40 \%$ & 53 & 57 & 80 & 89 & 160 & 164 \\
\hline & $50 \%$ & 66 & 73 & 91 & 96 & 149 & 156 \\
\hline
\end{tabular}

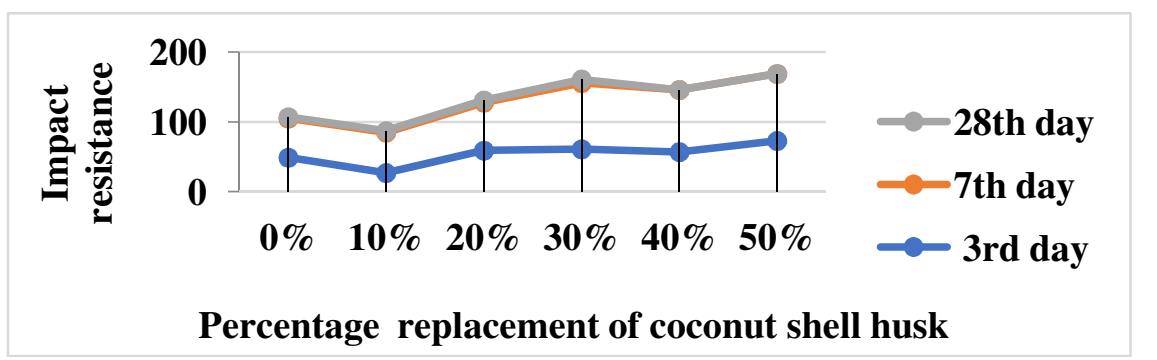

Fig.-11: Graphical Representation of Impact Resistance Test Results

\section{CONCLUSION}

- The replacement of fine aggregate as a coconut shell husk of 10\%, 20\%, 30\%, 40\%, 50\% compared with the conventional concrete, it is found to have same the strength with minor decrease when the percentage replacement of husk has been increased.

- The optimum replacement of fine aggregate by coconut shell husk is $40 \%$.

- Due to the use of coconut shell husk, we can save the natural resource by replacing instead of river sand.

- By implementing the replacement of fine aggregate by coconut shell husk, it will reduce the total construction cost.

- From the environment point of view, the coconut shell obtained as raw waste is reused in the production of concrete as fine aggregate.

\section{ACKNOWLEDGMENT}

This study was supported and grant of permission to use the lab facilities was given by SRM Institute of Science and Technology, Chennai.

\section{REFERENCES}

1. S. Prakash Chandar, K.Gunasekaran, K. Prasanth et al, Rasayan Journal of Chemistry, 11, 702(2018), DOI:10.7324/RJC.2018.1123003.

2. S. Prakash Chandar, K. Gunasekaran, V. P. Nabeel Babu et al, Rasayan Journal of Chemistry, 11, 640(2018), DOI:10.7324/RJC.2018.1123011.

3. S. Prakash Chandar, K. Gunasekaran, N. Sai Sandeep et al, Rasayan Journal of Chemistry,10, 528(2017), DOI:10.7324/RJC.2017.1021636. 
RASĀYAN J. Chem.

Vol. 12 | No. 3 |1621 - 1626| July - September | 2019

4. R. Ramasubramani, K. S. Sathyanarayanan et.al, Rasayan Journal of Chemistry, 9, 706(2016).

5. K. Divya Krishnan, P. T. Ravichandran, V. K. Gandhimathi, Rasayan Journal of Chemistry, 10, 600(2017), DOI:10.7324/RJC2017.1021677.

6. S. Prakash Chandar, K. Gunasekaran, K.S.Satyanarayanan et.al, European Journal of Environment and Civil Engineering, DOI:10.1080/19648189.2017.1418435.

7. K. Gunsekaran, S. Prakash Chandar, R. Annadurai et.al, European Journal of Environmental and Civil Engineering, DOI:10.1080/19648189.2016.1144540.

8. V. Sumitha, P. T. Ravichandran, Divya Krishnan K., International Journal of Engineering \& Technology, 7, 411(2018), DOI: 10.14419/ijet.v7i2.11507.

[RJC-5228/2019] 